\title{
GRABBING 'GREEN': CYNICAL REASON, INSTRUMENTAL ETHICS AND THE PRODUCTION OF 'THE GREEN ECONOMY
}

\section{Kenneth Iain MacDonald}

\begin{abstract}
Department of Human Geography and City Studies University of Toronto, Scarborough
\end{abstract}

\section{Abstract}

This paper traces the institutionalization of Environmentalism as a pre-condition for the production of 'The Green Economy,' particularly the containment of the oppositional possibilities of an environmentalist politics within the institutional and organizational terrain of a transnational managerial and capitalist class. This is a context in which many environmental organizations - once the site of planning, mobilizing and implementing opposition and resistance to the environmentally destructive practices of corporate industrialism - have become part of a new project of accumulation grounded in enclosure, access and the production and exchange of new environmental commodities. This transformation reflects what Sloterdijk (1988) has termed cynical reason - an enlightened false consciousness; and my concern in the paper is to think through 'The Green Economy' and its coincident instrumental ethics as an iteration of cynical reason and an expression of institutionalized power. Specifically, I focus on the development of 'global environmental governance' as a statist project that concentrates sanctioning authority and resource allocation in centers of accumulation (e.g., the Convention on Biological Diversity and its funding mechanism the Global Environment Facility) and facilitates the containment of Environmentalism as an oppositional politics through demands that it assume conventional forms of organization, projectification and professionalisation and through facilitating a redefinition and redeployment that shifts environmentalism from a space of hope to an instrumentalist mechanism in rationalist projects of accumulation.

Keywords: cynical reason, environmentalism, professionalism, environmental governance, instrumental ethics

El Saqueo Verde: Razonamiento Cínico, Ética Instrumentalista y la Producción de 'La Economía Verde'

\section{Resumen}

Este artículo delinea la institucionalización del Ambientalismo como pre-condición para la producción de 'La Economía Verde', especialmente la supuesta posibilidad de generación de acciones políticas opositoras dentro del terreno institucional y organizacional de una clase gerencial transnacional y capitalista. Este es un contexto en el que muchas organizaciones ambientalistas - que fueran el lugar para planear, movilizar e implementar oposición y 
resistencia a las prácticas ambientalmente destructivas del industrialismo corporativo - se han vuelto parte de un nuevo proyecto de acumulación basado en el cercamiento (enclosure) y la producción e intercambio de nuevos comodities medioambientales. Esta transformación refleja lo que Sloterdijk (1988) llamó 'razonamiento cínico', una falsa conciencia liberal. Mi objetivo en este trabajo es el de pensar a 'La Economía Verde' y su coincidente ética instrumentalista como una iteración de razonamiento cínico y una expresión de poder institucionalizado. Específicamente me concentro en el desarrollo de la 'gobernanza global medioambiental' como un proyecto estatista que concentra a la autoridad y los recursos en centros de acumulación (por ejemplo el Convenio sobre la Diversidad Biológica y su mecanismo fundacional, el Programa Ciudadanía Ambiental Global) y que fomenta la contención del Ambientalismo como supuestamente opositor mediante la demanda de que éste asuma formas convencionales de organización, proyección y profesionalización, y mediante una redefinición que lleva al ambientalismo de un espacio de esperanza a un mecanismo instrumentalista de proyectos racionalistas de acumulación.

Palabras clave: razonamiento cínico, ambientalismo, profesionalismo, gobernanza ambiental, ética instrumentalista

\section{Introduction}

There is little doubt that capitalism has 'grabbed' green. This inversion of the more conventional phrase - 'green grabs' - is meant to signify the involvement of capital and the state in redefining 'the environment' to aid accumulation; a project increasingly grounded in the instrumental use of 'the environment' by actors conventionally associated more with social and ecological marginalization than environmental well being. While activists often see this as simply 'greenwashing,' the capacity to effectively use a concern for the environment as the basis for new forms of accumulation is much more complex. On the one hand, it is grounded in the merger of ecological and economic epistemologies that not only privileges the use of market devices in attaining environmental objectives but also actively redefines what those objectives should be. It also points to a transformation of environmentalism through a long but steady process of institutionalization. This institutionalization has worked to configure institutions of environmental governance as vehicles that can be used in the interest of capital accumulation. The most recent manifestation of this is the role played by institutions like the United Nations (UN) framework conventions in the production of 'the green economy' and in promoting the more recent shift to 'green growth.'

This paper builds on work that reveals how, over the past 20 years, many environmental organizations once the site of planning, mobilizing and implementing opposition and resistance to the environmentally destructive practices of corporate and industrial actors - have become part of a new project of accumulation grounded in enclosure, and the production and market exchange of new environmental commodities (Brand and Gorg 2008; MacDonald 2010a; Corson and MacDonald 2012). This shift in the oppositional politics of organized environmentalism ${ }^{1}$ to one of accommodation has occurred as states have centralized institutions for 'global environmental governance,' and reflects its subordination to the interests of a transnational managerial and capitalist class, and the institutional and organizational forms designed to satisfy those interests. One of the consequences of this dynamic has been the formative stages in reshaping the construct of sustainable development into a more coherent market-based technological fix billed as 'The Green Economy.' Indeed, the production of 'The Green Economy' and particularly its capacity to legitimate accumulation through a rhetoric of environmentalism relies upon the capture and translation of the transformative oppositional potential offered

\footnotetext{
1 In using the phrase 'organized environmentalism,' I am referring to variants found behind the walls of large NGOs, and not, for example, to the 'environmentalism of the poor' (Martinez-Alier 2003). However, as neoliberalization led to a marked split between variants of environmentalism it also established an institutional context in which organizations with distinct political histories become entrained in dominant ideological shifts.
} 
by environmentalism; a form of containment made easier by the bourgeois characteristics of organized environmentalism.

This translation reflects what Sloterdijk (1988) has termed cynical reason - what he calls an enlightened false consciousness; enlightened because actors know the 'falsehood' and the particular interest behind an ideological universality but continue to attach themselves to it. My concern in this paper is to think through 'The Green Economy' and its coincident instrumental ethics as an iteration of cynical reason and an expression of institutionalized power. Specifically, I focus on the development of 'global environmental governance' as a statist project that concentrates sanctioning authority and resource allocation in centers of accumulation (e.g., the Convention on Biological Diversity and its funding mechanism the Global Environment Facility) and facilitates the containment of environmentalism as an oppositional politics through demands that it assume conventional forms of organization, projectification and professionalization, and through facilitating a redefinition and redeployment that shifts environmentalism from a space of hope (Harvey 2000) to an instrumentalist mechanism in rationalist projects of accumulation.

The empirical evidence of the integrated interest of capital and the state that underpin the shift toward a reliance on market mechanisms in environmental governance and management has grown substantively over the last decade (Castree 2008; Brockington and Duffy 2011 Bond 2011; Kelly 2011; Büscher et al. 2012). More recently this work has revealed how the configuration of power around these interests has created increasingly fluid boundaries between 'private' and pseudo-public actors like non-governmental organizations (NGOs), even as those actors continue to invoke a rhetoric of differentiation between business, government, and NGOs (MacDonald 2010a, 2010b; Corson 2010). Perhaps the clearest example of this is that the registers used by some environmental organizations to define themselves and their actions - the vocabulary of 'green' and 'greens' - have traveled beyond the ideological barricades of environmental organizations and been adopted by the corporate sector, just as the language and corporate structure of business and management has become common parlance within many environmental organizations. Given its origins as an oppositional politics, this transformation raises important questions for the 'modern environmental movement'; particularly, how has environmentalism come to work in the service of capital accumulation?

\section{Institutional Dynamics and the Containment of Opposition}

For the past 10 years I have been building a project of organizational and institutional ethnography observing, from within environmental organizations, the workings of people who call themselves environmentalists, and tracking organizational relations and dynamics to understand how those 'workings' are aligned and articulated with the interests and dictates of institutions of governance, like the UN Convention on Biological Diversity (CBD), born of neoliberal restructuring (MacDonald 2010a, 2010b; MacDonald and Corson 2012; Corson and MacDonald 2012; MacDonald in press). My 'field sites' have been in the offices of environmental organizations, mostly large conservation organizations, watching programs of work take shape, occasionally providing input, watching staff turnover (and listening to staff talk about that turnover), tracking the allocation of resources, watching fragile social ties between NGO staff and employees of corporations - most of them extractive industries - turn into what Latour (2005) has called durable associations, as relationships built on social connections became partnerships structured through legally binding contractual agreements (MacDonald 2010a). These agreements primarily involve staff exchanges covering periods of two-three years, and the implementation of pilot projects with the corporate partner covering the cost of coordinating the agreement. ${ }^{2}$ The social relations created through these agreements can often lead to a 'revolving door' syndrome in which the boundaries between resource

2 As an example see the terms of the partnership between the International Union for the Conservation of Nature (IUCN) and Shell. (http://www.iucn.org/about/work/ programmes/business/our_engagements/bbp_shell/resources/ agreement/ ; accessed Oct. 13 2012) 
users and those conventionally seen to be responsible for monitoring or regulating resource use become highly permeable (Meghani and Kuzma 2011). ${ }^{3}$

Some of the most insightful aspects of the research have involved traveling with official delegations to the meetings of institutions, like the Convention on Biological Diversity, that since 1992 has configured an institutional network of environmental actors. This has let me observe the development and practice of strategies to influence the direction of biodiversity conservation policy, the CBD program of work and the direction of funding channeled through the GEF. But it has also provided insight into organizational priorities, anxieties - expressed in concerns over 'message control' - and, increasingly, brand liability protection. As a simple example, during the 2006 CBD Conference of the Parties (COP) in Curitiba, Brazil, a red alert went up in the briefing room of an environmental organization when the representative of a mining industry trade association referred, in a comment from the floor during a working group session, to their 'partnership' with the environmental organization. During the next morning's briefing staff expressed their concerns with these remarks and the head of delegation queried them: 'Why did he raise it? Who heard? Did anyone comment? How are we going to address this?' The outcome of the conversation was that someone should speak to him and make it clear that the organizations are engaged in a 'dialogue' not a 'partnership.'

These anxieties and the struggle over semantics exposed a tension within the conservation organization at the time. On the one hand they did not want to be seen to be antagonistic toward business, as this might alienate relations with some parties to the CBD and compromise their growing 'partnership' with business associations like the World Business Council on Sustainable Development, but at the same time they did not want to be seen to be too close to the mining industry, and potentially alienate their membership

3 For example the recently hired head of IUCN's Business and Biodiversity program had spent 17 years working for Hocim (one of the world's largest aggregate miners and cement producers) most recently managing Holcim's partnership with IUCN. base. By the next COP in Bonn, Germany two years later, things had changed. The presence of corporate actors was much more visible and mention of partnerships with the private sector did not raise an eyebrow in the delegation briefing room. If anything they were actively encouraged. This change in attitude, however, was not unique to the organization. It was located in a much broader shift within the organizational and institutional field of biodiversity conservation.

The beginnings of this shift can best be located in 2002 with the UN commitment to the promotion of public-private partnerships during the World Summit on Sustainable Development in Johannesburg. The Johannesburg summit was a field-configuring event (Lampel and Meyer 2008) a term used to describe events that temporarily bring actors together and construct arenas for demonstrating, displaying and promoting perspectives, mechanisms, techniques and practices; provide the institutional context and opportunity to transform contestation into legitimated outcomes, and shaping disparate organizations and individuals into a 'community' that shares a common meaning system (Scott et al. 2000). Johannesburg laid the groundwork for the 2006 CBDCOP in Curitiba, which passed a number of decisions, explicitly encouraging the role of corporate actors in the CBD program of work, even as strategic resource decisions highlighted the lack of sustainable financing to carry out that program of work. Following that COP the CBD Secretariat established a business and biodiversity initiative; the G8 had sponsored a massive study into valuation - the Economics of Ecosystems and Biodiversity (TEEB) headed by Pavan Sukhdev a finance capitalist who had spent most of his career at Deutsche Bank; a 'high-level' conference numerous on business and biodiversity had been convened under Portugal's presidency of the EU; and EU states, primarily Germany, host of the 2008 CBDCOP, had initiated numerous business and biodiversity programs (MacDonald 2010a; MacDonald and Corson 2012). In essence, the institutional groundwork had been laid to transition from the loosely defined concept of sustainable development, to the implementation of a series of market-based mechanisms collectively defined as 'The Green Economy.' Environmental 
organizations, if they were not already leading the charge to the dominance of market logics, have quickly followed suit.

While some explain this form of accommodation as cooptation or 'selling out,' (Trumpy 2008), this is far too simple. It holds to the notion of rigid boundaries across sectors often described as business (or corporate), government, and NGO (occasionally replaced by 'civil society') and treats each of these as monolithic. Such explanations also ignore the institutionally configured relations of power within which environmental organizations operate, and how these relations work to entrain organizations within dominant institutional logics. A fuller explanation is much more complex and requires an assessment of the organizational dynamics that have compromised the oppositional potential of environmentalism.

\section{Cynical Reason and the Restructuring of Organized Environmentalism}

As the 'space of hope' once occupied by environmentalism recedes into a form of resignation or a question of 'practicality' organizational leaders, themselves increasingly part of a transnational managerial capitalist class (Corson and MacDonald 2012), highlight the 'need to engage with business' even as they rely increasingly upon those business actors and associated states for increasing shares of their operational funding (Brechin 2009). It is this resignation and the rhetorical appeals to pragmatism that makes cynicism a useful lens through which to understand how "environmentalism became a politics that can be enlisted, contained and directed toward the interests of capital accumulation" (MacDonald and Corson 2012: 180). As Huyssen's (1988) commentary on Sloterdijk points out, cynicism is no longer the quality of the lone, acerbic critic battling dominant forces. With the "passing of defiant hopes" that marks contemporary environmentalism it now "successfully combines enlightenment with resignation and apathy" (Huyssen1988: xvii). What is labeled 'pragmatism' by leaders of environmental organizations, then, is expressive of Sloterdijk's "enlightened false consciousness" in which "the compulsion to survive and desire to assert itself have demoralized enlightened consciousness. It is afflicted with a compulsion to put up with pre-established relations that it finds dubious, to accommodate itself to them, and finally even to carry out their business" (Sloterdijk 1988: 6). If we think of variants of environmentalism as having their roots in a form of enlightened consciousness (or at least using enlightenment as a framing narrative) the compromise of oppositional politics is a reflection of this willingness to accommodate relations that have facilitated the environmental degradation of corporate industrialism, but also the influence wielded by those corporate actors in setting policy and public funding priorities. The evidence for this is rife as environmental organizations assume corporate forms, link with corporate actors ${ }^{4}$, and even carry out their business (MacDonald 2010b). ${ }^{5}$

This structured alignment of interests reflects Sloterdijk's (1988) notion of cynical reason - what he terms a modernization of false consciousness in which "the old strategies of the enlightenment- from the public exposure of lies, to the benign correction of error, to the triumphant unveiling of a structurally necessary false consciousness by ideology critique-will no longer do ... because the false consciousness they attack is already reflexively buffered" (Huyssen 1994: 160). Žižek (1989: 29) commenting on Sloterdijk puts it this way: if Marx's very simple definition of ideology was "they do not know it, but they are doing it," what Sloterdijk is saying is that "they know very well what they are doing, but still, they are doing it." Sloterdijk sees cynicism as the dominant operating mode in contemporary culture, both on personal and institutional levels, and as manifest in political disillusionment. But in keeping with his point that the critique of ideology is futile against cynical reason, he conceives of the phenomenon of cynicism as split within itself pitting "the cynical reason of domination and self-domination" [the cynicism of power and

4 Through, for example, engaging in partnerships, exchanging staff, sharing technologies, engaging in joint ventures.

5 Through, for example, producing databases for corporate use, providing public relations support, providing staff expertise, or providing indirect access to public resources and funding (MacDonald 2010a). 
its institutions] against a revolt of self-assertion and self-realization that he calls kynicism - a response to the "cynicism of domination with irony, defiant body action, or strategic silence" (Huyssen 1988: 15-16).

The cynical reason of domination and selfdomination in organized environmentalism is most evident at moments of conflict when the structures of conformity and normativity that underlie domination are exposed to view. For example, during the opening ceremonies of the 2008 World Conservation Congress (WCC) in Barcelona there was a scene on stage that fits like a key into an analysis of the cynical reason that underpins the production of 'The Green Economy.' The hall had filled with thousands of so-called experts in biodiversity conservation and environmental management; dignitaries and royalty had been ushered in and shown to their seats, their red neck straps distinguishing them from the more common green worn by the rest of the audience. The master of ceremonies had taken stage; the requisite politicians had been introduced; monarchs congratulated us on our achievements. ${ }^{6}$ Only then did the core of the spectacle begin. The strains of appropriately anxious music filled the room, and a massive screen filled with images telling us of the scale of the problems we confront, with the core message delivered via prerecorded video by the spirit of televisualised nature, David Attenborough - his head, projected onto a huge video screen high above the audience. Tumblers whorled across the stage and acrobats spun gracefully as they climbed and wound themselves around five long, red, cloth banners hanging from the ceiling of the stage. As the acrobats spun, the jugglers juggled and the clowns entertained the gathered nobility; the core messages of the Congress were revealed to us one by one as the banners were turned - "... SUSTAINABILITY, AWARENESS, EQUITY, BIODIVERSITY.” However, as the final banner calling for "ACTION" was turned, two young people, a man and a woman

6 The consecration of nobility has been an enduring component of establishment conservation. At the WCC, for example, conservation organization leaders were hosted on the royal yachts moored in the harbor and the representative of a Crown Prince of Abu Dhabi announced a \$25 million fund for species conservation (which, in 2008, amounted to 2 hours of Abu Dhabi's oil revenues). dressed plainly in jeans and T-shirts, walked on stage, unfurled a banner and stretched it between them. The banner had a simple message asking for help to save a green space that was threatened by development on the outskirts of the city.

The circus performers clearly feigned surprise, making it hard to believe that they were not part of this orchestrated intrusion. The timing was too perfect and the space too heavily securitized for these protestors not to have had 'inside help'. But the disruption was remarkable in its simplicity. Into this spectacular ceremony - the kind of spectacle that has become the norm at these events - walked two young people asking for help to save an urban green space. The message was strikingly simple and the intervention more physical - a contrast to the grand spectacle of video, sound and celebrity we had been watching. And that seemed to contribute to the audience reaction - almost as if people were asking, "is this ironic?" But rather than applause or shouts of support, the protestors were greeted with astonishment. Confusion reigned as people wondered whether this was 'officially' part of the spectacle. Within seconds a number of security personnel rushed on-stage, ripped the banner from their hands, grabbed them by the arms and marched them off the stage. The moderator made a joke, and the show went on.

This moment deserves a closer look. Its irony is delicious - a scene of environmentalists protesting at a meeting of self-proclaimed environmentalists - and provides a useful lens into the cynicism of contemporary organized environmentalism. For here were two young people - doing what 'stereotypical environmentalists' do - engaged in bodily disruption, asking for help, and seeking to communicate a message about the importance of the world around them and our role in it. And what did they get for their trouble? Cast off the stage. Dragged from the assembly, as if they had committed some crime. Their message was apparently too parochial for the 'weightier' scalar concerns being discussed at this 'World' Conservation Congress. The contrast was stark - action, self-awareness, and robust politicized performance staring into the face of cynical domination, its institutions and its concern 
with protocol. It is this rupture between the action of bodily intervention and the sedate qualities of a professionalized, organized environmentalism that points toward the political disillusionment that Sloterdijk understands to be a manifestation of cynicism.

This disillusionment, however, is not necessarily explicit. It is subtler and lies in the transformation of the oppositional potential of environmentalism, as it existed in the late 1960s, into an institutionalized form that has witnessed a continuing degradation in environmental conditions. The failure of the promise of environmentalism has led to a general disillusion in terms of achievement witnessed in the rollback of effective policy and legislation, the reduction in the commitment of public funds to deal with environmental problems, the rise in so-called voluntary regulatory regimes, the rise of market logics and market-based mechanisms in the institutions and organizations responsible for environmental governance, and, as witnessed in Barcelona, an increasing willingness to label some of its own - those who refuse to readily conform with these changes - as 'elements' or 'radicals' (Schlossberg and Dryzek 2002).

However, it is important to recognize that this disillusion is not expressed as detachment. On the contrary, it is a function of increased engagement; but a kind of engagement that differs from the oppositional politics that characterized environmentalism in the late 1960s (Rootes 2003). What we see today is an environmentalism contained by a politics and practice of achievement aligned not only with new institutional configurations of power, but also with conventional societal notions of success. As Igoe (2010), and Büscher (in press) among others have shown, institutional and organizational spaces have become the public face of contemporary popular environmentalism. But for that to happen, environmentalism had to first become cultivated, organized, corporatized and professionalized around bourgeois labor subjectivities with accordant structures of individual aspirations, desire and achievement. To understand how this moment came to pass - to understand how this gap between the subversive derision of Sloterdijk's kynicism and the cynical reason of environmentalism grew so wide (with accordant scenes of environmentalists protesting 'environmentalists') - we need to step back and revisit the dynamics of contemporary environmentalism.

Contemporary environmentalism can be interpreted as the outcome of a "struggle between opposing consciousnesses: the cynicism of power and its institutions vs. the kynical revolt from below which responds to the cynicism of domination with satirical laughter, defiant body action, or strategic silence." (Huyssen 1983: xvi). It is hard not to locate the mechanisms and practices of post-1968 environmentalism in these depictions of performative agency with a repertoire of contention rich in tactics of satire, irony and explicit bodily action (cf., Tarrow 1994; Tilly 2006). Its opposition was not necessarily expressed in terms of rationalism, even as it was never divorced from instrumental representations of objectivity and rationalism. It is only in the subsequent years that environmentalism, at least in its organized western variants has been captured by rationalism and professionalism (e.g., Torgerson 1997). This is not to say that there is not still effective environmental opposition, but that this continues to occupy the realm of sub politics (Beck 1997), a realm that can be thought of as containing surplus environmentalists available for capture (i.e., youth developing a concern for environmental wellbeing that can subsequently be turned toward individualized instrumental, rather then collective, gains). Which leaves a question: through what mechanisms is environmentalism captured by rationalism?

One explanation, explored by others, is that environmentalism, as a named social movement, has always been bourgeois (Guha and Martinez-Alier 1997) and that its organized form simply represents an expression of the 'will to power' manifest in professionalism and corporatization. As much as it is affective practice, environmentalism was raised to a metamoral standpoint through the theory and practice of ecology. But what began as ecological understanding of the world led to action that formed the basis of a collective social movement. And even as the basis of this movement, as environmental justice scholars have pointed out, was grounded in bourgeois privilege, it was action that sought to distinguish itself from a bourgeois 
ego by residing in the realm of subpolitics, even as it wanted to gain broader political expression. If part of the strength of environmentalism was its capacity to link science and action with hope, it also arose from its alignments with core interests of the state as they developed through the 1960s and early 1970s. An intensive period of institutionalization occurred as governments established agencies to deal with environmental issues and enacted legislation required to establish regulatory frameworks (Schlossberg and Dryzek 2002). This was matched by the growth of environmental movement organizations that claimed a public mandate to oversee and monitor the actions of the state. This institutionalization of the movement intensified as the core interests of the state shifted away from a focus on the environment with the onset of neoliberalization. ${ }^{7}$ On the one hand this provided a boon for environmental movement organizations as it provided the ability for them to claim greater responsibility for environmental management and conservation, but it simultaneously compromised their access to policy setting venues, particularly for organizations that retained the stance of an oppositional politics. Environmentalism fragmented as collective activism gave way to an organizational form that reflected the desire for a stable presence to influence policy, to produce knowledge, to access power; and the environmentalist-activist-self was supplemented, if not replaced by a bourgeois labor subjectivity in which, to paraphrase Sloterdijk (1988: 63) the aspirational 'I' rather than the collective 'we' can develop an awareness of progress, take pride in the cultivation of one's own skills and expertise; experience fulfillment in feeling part of a project or an innovation, and "feel the triumph of gaining a political say." Of course, this does not happen without discomfort as, in the same moment, it is difficult to maintain this conviction in the face of the stringency of a workplace that cares less for one's environmentalism than for one's labor; less for one's love of 'nature' or 'the planet,' than for one's output so long as it is useful to the shifting objectives of the organization (Eyerman and Jamison 1989;

\footnotetext{
$7 \quad$ Indeed some scholars understand the modern
} environmental movement as a brief moment between the development of the forces that shape the movement and the period of its institutionalization (Eyerman and Jamison 1989, Rootes 2004).
O'Doherty and Willmott 2001; Lewis 2003). The trend to professionalism creates boundaries grounded in normative behavior that relegate those who object or act counter to a 'professional demeanor' to the margins and subject them to accusations of engaging in counter-productive 'extreme' or radical behavior.

But even in this cultivation of the alienated 'environmentalist' self, professionalism works to re-establish a different commonality, a "true professional faith", ostensibly grounded in 'objectivity' and a supposedly shared beliefs and commitments (Atkinson 1995: 263; Rigling Gallagher 2007). This refrain echoes in the plenary rooms of organized conservation events as cynical organizational leaders speak of common goals, or refer to 'we environmentalists', even as their current and former employees talk of how their own organizations are divided into resource-centered units responsible for securing their own funding and an organizational 'climate' in which units do not speak to each other for fear of compromising access to a funding source. ${ }^{8}$

While this 'will to power' argument is convincing, the exercise of a 'will to power' requires a political arena in which it can be realized. This is where institutionalization becomes crucial as, over the past 20 years, institutional forms of transnational environmental governance that provide just such a political arena have been brought into being. Functioning as centers of accumulation (Latour 1999; Rosen 2000), institutions like the Convention on Biological Diversity and related elements of the international negotiating process, like the recent $\mathrm{RIO}+20$ United Nations Conference on Sustainable Development, consolidate state sovereignty in the guise of addressing urgent international problems, provide program objectives, and channel funding through mechanisms like the GEF to meet those objectives, creating coercive conditions under which organizations secure institutional sanction and legitimation and the material support that comes with it. They also, in the guise of a creating 'balanced,' deliberative space create a competitive arena in which 'new voices' are 'invited' to participate in deliberations, creating the conditions

8 Fieldnotes, Gland, Switzerland, June 2011. 
for transcultural encounters in which actors learn from each other. Corporate actors learn the language of social movements and 'build' the capacity to more effectively inhabit the spaces of new public interest, like environmental organizations, and institutions of environmental governance. And environmental organizations develop the flare for managerial logics, message control, branding, commodification, trademarks, and managing competition. In short, at least in organizational form, they become much more alike. Through a slow but steady form of intersubjectivity, evident in mechanisms like staff secondments, joint panels, and partnerships, environmental organizations develop a corporate structure and hierarchy (Harter 2004; MacDonald 2010a).

It is in these contexts that we see the formation of a transnational managerial class reflected in a disentanglement with those parts of the environmental movement that have become known as 'those elements,' or 'radicals,' and new entanglements with actors that just 20 years ago would have been anathema to most environmental organizations and corporations. This was most recently evident during the 2012 World Conservation in Jeju, Korea, when at the end of every day, the organizers convened "World Leader's Dialogues," faux debates built around rhetorical questions that featured CEOs of Shell and Syngenta, the President of the World Business Council on Sustainable Development, heads of large environmental organizations like the International Institute for Environment and Development, and career bureaucrats from institutions like the GEF. This was a spectacle that effectively revealed shifting power relations configured around transnational environmental governance, and that subordinate actors in the audience could observe and use in calculating their own practices of alignment and articulation. It was also a stage for "those who are a priori the winners - the elite, the rich, the ambitious, those who feel they are best at making politics" (Sloterdijk 1988: 67). This kind of event can in fact be best read as a visible expression of the relations of power configured by issues of environmental governance. In many ways, the lobbying is complete, blocs have been formed, and events like the WCC reflect strategy and agenda setting moments in a hegemonic process that reflects the mutual interests of capital, the state and NGOs. We can think of this new alignment as marked by a "characteristically cynical cadre politics" in which the leadership - a transnational managerial capitalist class - communicates an expectation of conformity and not so subtly works to exclude those who do not conform (Sloterdijk 1988: 69). But what can be revealed as cynical is rarely explicitly presented as cynical. Indeed, an outcome of the exercise of cynical reason has been the explicit emergence of an instrumental ethics expressed most clearly in representational practices used in the promoting the register of this new cynical cadre politics within organized environmentalism.

\section{Instrumental Ethics and the Manifestation of Cynical Reason}

The ramifications of this practice of cynical reason has been the production of an instrumental ethics; by which I mean a form of ethical practice that has become tethered to and justified in relation to organizational projects and their objectives rather than an expression of principles. This is an ethics that defines its aim through an assumed and asserted morality of the work done through those projects. The capacity to adhere to this belief, for environmental organizations, is facilitated by the fact that we live in an age in which the reach of our actions far outstretches our conception of moral responsibility and in which we devolve responsibility for caring about things like environmental degradation onto agencies (e.g., environmental organizations) or institutions (e.g., the UN Framework Conventions) that claim the mandate, skill and capacity to act on our behalf but do not react well if we pay too close attention to, or try to intervene in, what they do (Baumann 1993 Fassin 2012). The professionalization of environmentalism has undermined morality as such - reducing responsibilities to contractual obligations, 'being-for-oneself' rather than 'being-for,' prioritizing technical practices of maximum efficiency over values, and using forceful means to secure questionable ends (Baumann 1993. What we see within contemporary organized environmentalism, empowered by norms of professionalism, is the remarkable absence of non-rational, 
non-utilitarian, and non-profitable moral passions. This is expressed in the production of 'the green economy, for example - the pinnacle of ecological modernization - with its re-assertion of the technoadministrative fix, grounded in a claim that dealing with environmental problems requires actions that are amenable to technical evaluation only. Of course, these actions are far from morally neutral and call for moral scrutiny and for some sort of ethical regulation. Yet the organizational and institutional actors responsible for this production operate under the guise that what they profess to be doing - 'protecting the environment' or 'putting in place the conditions for sustainability'- are inherently moral and it would be redundant to subject specific projects to ethical scrutiny. But in refusing reflection or introspection they confirm that " $[\mathrm{m}]$ orality is not safe in the hands of reason, though this is exactly what the spokesmen for reason promise," (Baumann 1993: 247) because it becomes instrumental - equated with an ethics that is delimited by purpose, convinced of its own rightness, circumscribed by identity rather than deliberative, and focused on the attainment of ends.

One of the clearest expressions of this is in the expression of unity and reason that are deployed in contemporary professionalized environmentalism. Below I use two examples to highlight this point. The first revolves around the role of an aesthetics (as much as a rhetoric) of balance that works to construct representations of unity the can subsequently be used in practices of material and ideological domination. The second reveals the deployment of an instrumental ethics in representations of rationalism that are used to legitimate contemporary valuation projects like TEEB, a UNEP-supported project focused on valuation, that epitomizes the merger of ecological and economic epistemologies manifest in the market logics which have come to dominate the institutional realm of transnational environmental governance and underpin 'The Green Economy' (MacDonald 2010a, MacDonald and Corson 2012).

\section{The Representational Politics of 'Balance'}

An aesthetics of balance implies symmetry. Indeed, as much as symmetry involves the reading of a very human construct into our surroundings, asymmetry is frequently seen as anomalous and an abomination in the representation of 'natural' beings. Through time Western aesthetes have read symmetry and balance into nature and subsequently 're-discovered' it as natural (Haraway 1989; Schama 1996). Increasingly, however, even as they are challenged by science, these representations of symmetry - an aesthetics of balance - are conflated with a politics of balance that seeks to secure space within arenas of governance for actors engaged in environmental degradation. While an aesthetic of balance and an associated rhetoric of justice are used to legitimate this participation, these efforts ultimately derive from an instrumental ethics attached to forms of bourgeois subjectivity. They are the direct outcome of the systemic effect of the ascendancy of market logics within institutionalized environmentalism and its entrainment of environmental organizations (Corson, Neimark, MacDonald, this volume).

The first example consists of two 'performances' of 'balance,' that took place in 2008; one during the opening ceremonies for the $9^{\text {th }}$ Conference of the Parties to the CBD in Bonn, Germany. The other produced for the World Conservation Congress in Barcelona. Notably, both of these performances assert that the role of institutions and organizations tasked with conserving biodiversity must 'balance' interests. The first performance was scripted and performed by members of Naturschutzjugend, the German Youth Association for the Protection of Nature (NAJU). As environmental negotiations have become ever more spectacular, orchestrated youth 'demonstrations' have become a standard, orchestrated, element of the opening ceremonies of these events. This engagement with 'youth' typically involves a performance designed to communicate the importance of taking action to secure an environmentally sound future for children. While these performances are always designed to communicate a message, the NAJU performance at COP9 was more nuanced than most. Three teens walked on 
stage carrying a tall balance scale, a basket hanging from either side of a central pole. As one of the teens began to recite the litany of damage done to the environment by human activity, another began to fill one of the baskets with objects representing the impacts - global warming, deforestation, habitat destruction, species depletion, and water pollution. The scale tipped ominously to one side. The narrator warned us that we are reaching a tipping point, a point of no return. But then the other teen began to fill the empty basket and the narrative changed tone- "It's not too late. We can still change." The basket began to fill with icons of hope ... reuse and recycling, alternative energy, new technologies, better policy. The baskets were soon even. The balance point was reached. And the narrative concluded with a demand: "we must all work together to achieve sustainable development." Aside from the troubling instrumentalism with which the construct and bodies of 'youth' are deployed at these events - the exploitation of 'the innocence of youth' and the ruse of participation - the staging and orchestration of this performance was notable. Expressed by the organizers as a challenge to the negotiators, this performance better served as an indication of the containment of opposition. These 'youth' were not protesting, but were a reflection of the ideological alignment that has happened as constructs of sustainable development and ecological modernization have enveloped potentially transformative oppositional politics (Worster 1993).

The second performance was produced by the World Business Council on Sustainable Development (WBCSD), a membership association composed of many of the world's largest corporations, which has built intensive relationships with many large environmental organizations since being formed just prior to 1992's UN Conference on Environment and Development. A central component of WBCSD's platform is their 'Future Leader's Team' (FLT) a program in which young management trainees of global corporations spent four months working together on projects designed to create "a global network of dynamic business leaders capable of acting as sustainable development ambassadors in their companies and in society." As part of their program for 2008, the FLT produced a video - 'Ecosystems in Balance: It's Everybody's Business' ${ }^{10}$ - to be launched at the World Conservation Congress. According to one FLT member, they were "trying to project a vision of the future and get people to think about collaboration was going to be needed between the social side and governments and business ... really the objective was to look at the future and how these three groups within society would have to interact to get things done."11

The video opens with two women and a man standing atop a white platform, clouds beneath them and surrounded by blackness. The platform is tipping ominously - clearly they are in a precarious position. The people strain to maintain their balance and not fall off the edge. The camera zooms in on each actor. The man is identified as 'Government.' One of the women is 'NGO,' the other is 'Business.' They share the platform with three large translucent cubes - a blue cube representing 'water,' a red cube marked 'climate,' and one filled with grain identified as 'food.' These slide across the platform as it tips first in one direction and then the other. While their faces initially express confusion and fear, they shift to determination as it becomes obvious that, if they are to save themselves, they must find a way to arrange the cubes in the center of the platform. But each of the actors carries a briefcase preventing them from using their hands to catch the cubes. 'Government' and 'NGO' drop their bags. 'Business' is reluctant but, at 'Government's' urging, she tosses her case to him and he drops it on the pile. We see that 'TRUST' is written in large white letters on the side of her bag. Then 'NGO' and 'Government' pick up their bags. 'Government' chases down the climate block and struggles to pick it up. But he cannot do it while holding his bag that we now see is marked 'FEAR'. He looks at his bag, then at the cube. Dropping his bag of FEAR, he is able to pick up the cube and carry it to the center of the platform. 'NGO' is now faced with a dilemma. She is holding

9 http://www.wbcsd.org/work-program/capacitybuilding/sdmi/future-leaders-team.aspx

10 http://www.youtube.com/watch?v=-aa-MWP2F4o

11 WBCSD Future Leaders Team participant, field notes, Barcelona, October 2008. 
two bags - 'TRUST' and 'IGNORANCE'- as the food cube slides toward her threatening to fall off the edge, carrying her with it. She looks at the bags, tosses 'IGNORANCE' over the edge, and pitches 'TRUST' to business. She stops the sliding cube, and pushes it to the center of the platform. Helping each other, 'NGO,' 'Government' and 'Business' stack the cubes and the bag of trust in the center and balance the platform.

The message of the WBCSD video is made almost painfully clear - balance can only be achieved if business, governments and NGOs work together. In doing so it reproduces the fallacy of clear and distinct boundaries between these actors - business, NGOs and government - when in practice these have long been diffuse and permeable as actors, interests and logics have flowed through them. Business has long cultivated the boardrooms of government and regulatory agencies and, over the past 2 decades, has increasingly colonized the offices and programs of environmental organizations and institutions that structure environmental governance (MacDonald $2010 \mathrm{a}, 2010 \mathrm{~b})$. This raises a question as to the purpose of the video. While the NAJU performance relies on a clear invocation of justice and its corollaries of equity and 'fairness' (as in the common symbol of the scales of justice), and the assertion that we can achieve justice and equity and 'save the planet' if only everyone would work together (so long as you ignore the obvious instrumentalist use of children and the notion of commensurate futures), the WBCSD video contains an assertion of equality between government responsibility, NGO activities and private sector interests - as if each is equal of the same consideration and importance. The message is void of any explicit notion of justice and fails to address any discrepancy in power or wealth among the actors but is grounded in the very familiar crisis narratives that have characterized the focus of environmental activism over the last century - 'It's not that its fair, it's not that it's just, it's that we're all doomed if we don't work together to achieve a balance.' It eliminates any recognition of the ideological and material basis of struggles over the environment - ejecting history and projecting a path to 'move forward.' This forward path is one in which large environmental organizations are entrained in the relations of power configured around institutions of environmental governance developed in the wake of the 1992 Earth Summit, an event that consolidated the authority of state sovereignty in environmental decision-making and concentrated state resources in the financing mechanisms designed to support the programs of work flowing from institutions like the UN Framework conventions. The offspring of neoliberalization, these institutions have readily served as vehicles to draw together the constituent elements of 'the green economy', reduce opposition and smooth the path for establishing common interpretive frames across a set of actors with the aim of configuring new channels of capital flow, new metrics to create commensurability across unlike elements of nature (facilitate economic exchangeability for things that are ecologically non-exchangeable), and the creation of new markets for their exchange.

The video is one component in a discursive configuration that would have us believe that realizing these pre-conditions - the 'green' equivalents of Rostow's (1960) 'transitional stage' of development - relies on 'working together,' code for aligning and articulating with the political projects of dominant actors and logics within the structures of environmental governance, to reorganize the materiality of the world. Human qualities - the briefcase of 'Fear' - must be cast off to rearrange the red block of 'Climate.' People must choose between the briefcases of 'ignorance' and 'trust' and work on the basis of 'trust,' in order to avoid all of us tipping over the edge.

It would be a fairly simple task to undermine the reductionist representation of the universal 'us' represented in this video, and to highlight the reasons that many people - in their struggles for secure livelihoods - have not to trust their governments or corporations who have partnered with environmental organizations (Goldman 2005). These forms of representation exercise a very real epistemic violence in their lack of willingness to recognize that fear is a warranted human quality and that trust is earned, most commonly in situations in which power is distributed symmetrically. Trust may well yet come when 
industry sends their legions of lobbyists back to the barracks and obeys statutory law rather than seeking to shape it to their advantage. But one clear problem with these representations is that the idea of unity upon which they are based conceives of the problem of environmental degradation, and the actors responsible for addressing it, in terms of an ideal aesthetics of balance, harmony and closure that is quite static, and obscures the dynamics of interaction and change that not only shifts the basis of the problem they represent but the affiliations of actors who claim to define and address it.

Rehearsing a worn out trope is not the only work done by the video. More importantly, it cultivates the bourgeois subjectivity that is at the root of cynical reason. And it is here, behind-the-scenes of video production, that we find the product of cynical reason - an instrumental ethics in which 'being-for-the-other' is simultaneously 'being-for-the-self' (cf., Baumann 1993; Fassin 2012). The story behind the video is not one of firm boundaries separating groups of actors. Almost in direct contradiction to its message, the video is an orchestrated project of coordination between governments (and their business and biodiversity initiatives), IUCN, a major NGO, and major corporations like Michelin. With the support of these actors, the video was produced in a kind of youth business camp supported by IUCN and the WBCSD - organizations with a long-standing 'relationship' ${ }^{12}$ - in which young managers were cultivating the skills of the self even as they engaged in the production of a video that sought to communicate the need to produce a collective 'we' necessary to the resolution of environmental problems - which they also play a major role in defining. This type of 'environmentalist' practice allows the members of the 'Future Leaders Team' to develop an additional 'skill set,' body of experience, and networked contacts to carry back to their corporations and leverage to their advantage. Of course, important questions come out of this attempt to represent the need to overcome problematic relations between NGOs, business and government when the video is explicitly an outcome of coordinated action among these actors - in essence,

12 http://www.iucn.org/about/work/programmes/ business/our_engagements/wbcsd/ an attempt to portray the definition of a problem in a way that legitimates the forms of association that have been brought about through the exercise of cynical reason.

Asking questions of coordination and intent is important, as these performances exist within a context - the meetings in which individuals and groups with differential access to decision-making and resources seek to shape environmental governance and management practices, legitimate knowledge, and regulate use. They are also emblematic of the creeping role of spectacle at those venues (MacDonald 2010b). The attempt to shape policy and practice not through insight, protest, or through reasoned argument grounded in evidence but through the capacity of visual and aural signifiers to communicate in ways that have impact, and align with practices increasingly familiar to, and legitimized by, the transnational managerial class responsible for setting policy and practice (Igoe, this volume, MacDonald 2010b).

Both of the spectacular displays I have described here help to constitute an 'aesthetic ideology of balance'. By diffusing identifiable responsibility for environmental degradation, and working to create an image of stability through the attainment of balance, they reflect an environmentalism transformed by cynical reason. But this aesthetics blinds us to the inequitable power relations that: a) define what constitutes 'the environment,' or 'biodiversity'; b) sanctions the production and translation of knowledge about 'the environment' and 'biodiversity'; c) sanctions what constitutes legitimate 'use' of the environment and biodiversity; and d) masks these practices behind a veneer of care and concern. To practice such aesthetics of balance is to simultaneously claim that we live in a world of rational decision-making in which clearly defined 'stakeholders' exist, with clearly defined interests, and that these can be equally represented in transparent processes of deliberation.

What these performances depict, then, is a process of 'problematization,' a mode of containment that brings problems into being and defines their parameters, while simultaneously marginalizing other 
ways of understanding and representing reality, and "of determining and constituting what exactly makes a problem" (Fassin 2012: 7). This problematization finds support in the representations of public and private agencies - such as those described above representations that are subsequently legitimated by scientists and politicians until they eventually become taken as self-evident, leading to different ways of justifying action. If the environmentalist kynic intervened bodily to challenge the rationalism of professionalization in order to 'save the planet,' the cynic invokes the need to satisfy the pre-requisite of rationalism in order to 'save the planet.' It is here that I think we can make a more specific connection between this form of representational practice with coordinated projects that represent themselves as grounded in just that belief. One such project is the widely touted TEEB, a social and material manifestation arising from and expressive of cynical reason in environmentalism.

\section{Materializing 'Balance': TEEB and the Legiti- mation of Natural Capital}

TEEB was first proposed by the German government at a 2007 meeting of the environment ministers of the G8 + 5, and began as a study on the economics of biodiversity loss. As it unfolded, TEEB convened a group of actors focused on the pricing and costing of ecosystems and biodiversity, producing reports aimed at distinct bodies of decision makers and putting in place demonstration projects oriented around ways to incorporate the productive value of ecosystems and biodiversity in national accounts. TEEB quickly established a presence through close integration with the United Nations Environment Program, European Union governments, and a multitude of environmental NGOs, and private sector actors primarily in Europe. With this institutional support, TEEB attracted the attention and resource investments of potential affiliates - politicians, scientists, businesses, bureaucrats and activists, who have quickly transformed what started out as a study into an institutionalized mechanism for valuing biodiversity.
In its various manifestations, TEEB applies conventional practices of cost accounting to an 'invisible' nature, serving as a vehicle to support other 'market mechanisms' developed on the presumption of what TEEB sets out to stabilize and make visible - the money generated by the functionality of ecosystems and biodiversity, and the loss of money incurred through ecosystem degradation and biodiversity loss (Robertson 2007; Corson and MacDonald 2012; Sullivan 2012 ). Despite the obvious problems of anthropocentrism in these calculations TEEB steps in to provide the value determinations - the number - that 'markets' require in order to be inserted into legal regimes of contractuality and moral spheres of equitable exchange (Radin 1996). In this practice of accounting - or valuation - it is the number as representation that simultaneously holds and issues an appeal-one of the reasons that ecologists and economists have so quickly bonded over constructs like 'ecosystem services.' The number is the expression of atomization and alienation that simultaneously appeals to and conveys the authority of 'objectivity.'

But what the number appeals to is distinct from (though integrally related to) the appeal that the number holds. Its attraction in many ways is commensurate with its ability to satisfy the desire of distinct actors and to make their interests, needs and responsibilities visible. It provides modellers with the opportunity to extend their models to a 'global' scale and for those models to have a policy impact; it gives activists and environmental organizations a metric to articulate with and gain access to decision-makers to make them see 'how the world really is' (e.g., foreground a competing vision). For those already 'on the inside' it provides them with a chance to gain status within their organizations; and for those with career aspirations that involve 'moving up' within organized environmentalism engaging with 'valuation' provides a vehicle to demonstrate a personal alignment with dominant institutional logics.

Yet, TEEB's primary claim-the 'real' benefit of the number-is a moral one. Despite its claim to objectivity, its legitimation is grounded in the representation of a faith in rationalism that can be read 
as the assertion of a very specific moral claim that lies in implicit assumptions about rationalism and policy-making. Even as the moral instrumentalism is implicit, the reliance of TEEB on rationalism for its own legitimation is readily apparent: "Understanding and capturing the value of ecosystems can lead to better informed... decisions; accounting for such value can result in better management; investing in natural capital can yield high returns; and sharing the benefits of these actions can deliver real benefits to those worst off in society" (ten Brink et al. 2009: 3). TEEB's visionary, Sukhdev, backstops this demand for metrics with one of his stock talking points, constantly repeating a page-worn phrase from management school texts: 'What you do not measure, you do not manage.' Trite though this sounds, it is significant as it frames the question not so much of manageability but legibility, or the way in which a world comes into being through the production and accumulation of 'facts' about that world. This problematization obscures any role of power in decision-making and the historical failure of 'rationalism' to address 'environmental issues.' It fails to acknowledge the political realities and social relations that contribute to and are produced by weak regulatory practice. Incapable or unwilling to define the problem as malignant - as a contradiction of capitalism - it treats it as benign, a function of not having the right 'information.' As such, it asserts claims about the morality of metrics - as if to say that what is fixed quantitatively can be acted upon qualitatively, that if policy-makers had the right (quantitatively correct) information, they would make the right (qualitatively correct-i.e., ethical) decisions. The assertion is that the right metric (value/ price) can achieve a given outcome mediated through rationalism, but that rational decisions cannot be made in the absence of 'the right' information. And this promise of rationalism as the intermediary between the metric (price) and the outcome (a nature capable of paying for its own protection) that TEEB holds out is its primary moral appeal. It is an instrumental ethics born of cynical reason.

\section{Conclusion}

Projects like TEEB are manifestations of the cynical reason that consolidated a new form of environmentalism during the last decades of the 20th century. This environmentalism, grounded in a faith in rationalism, and cultivated both through the coercive directives of neoliberalization and the intersubjectivity of class associations, has helped to constitute a body of organized environmentalism that draws together, under ideologies of professionalism, bureaucrats, employees of environmental organizations, entrepreneurs, capitalists, financiers and labels them 'environmentalists.' But these actors are not defining and accommodating 'the environment' in new ways out of a concern for general ecological well-being, a looming production crisis, or because of stringent regulatory regimes. They are accommodating it because it has been translated into and represented in ways that make new forms of accumulation possible.

This is not to say the situation on the ground is radically changed - that human environment relations have radically altered, or that our understanding of these relations has gone through some transformation, it is rather that 'the environment' has taken on a new meaning - the assertion of the environment as natural capital - and that the organizational and institutional forms that claim responsibility for the environment have begun to justify their actions in a different way; shying away from oppositional stances, increasingly invoking economic rationalism as a grounds for their interventions, and mobilizing intervention around the production of new kinds of environmental commodities, metrics, social relations, and practices of governance in which attention is focused on a form of valuation that facilitates universal commodification and exchange. Cynical reason is central to this dynamic and is most clearly seen in the daily practices of those who sit close to positions of power, in the everyday actions of those who are part of the institutional network of actors and mechanisms that constitute transnational environmental governance (Marcus 2000). It is these actors that Sloterdijk (1988: 44) characterizes as modern cynics who, in their exercise of an enlightened false consciousness, do not see 
their way of existing or acting as something that does damage to others, "but as participation in a collective, realistically attuned way of seeing things." It is this pragmatism that led to the transformation of environmentalism and it is through this transformation that the 'The Green Economy' is being brought into being. 'The Green Economy' as an ostensible object is only possible through cynical reason dependent upon professionalization and alienation of environmentalists from 'environmentalism' - meaning that for 'The Green Economy' to come into existence, subjectivities must change, metaphors must become ontologies (e.g., natural capital), new metrics must come into being, and with them, new social facts.

It is because of the everyday qualities of cynicism that institutional ethnography is such an important methodological practice for revealing cynical reason in action and for understanding its presence in ideological formations, like environmentalism, humanitarianism and development, that continue to be broadly seen as altruistic even as the politics form which they arose have become increasingly contained and compromised (Ebert 1999; Fassin 2012). An ethnographic standpoint - something missing in much contemporary work on cynicism - allows for the observation of many people operating within and especially leading environmental organizations today. It allows access to the ways in which they view themselves as pragmatists, as different from, and in fact superior to, idealists (Sloterdijk's kynics), and as having overcome the 'naivety' of environmentalism. This view of the self is the effect of cynical reason which has witnessed the integration, or translation, of a naive environmentalism into a will to self-preservation - a will to power - that expresses itself in the organizational and institutional form necessary for the production of 'The Green Economy,' and the ability of various interests including finance capitalists to 'grab green.'

\section{References}

Atkinson, R. 1995. A Dissenter's Commentary on the Professionalism Crusade. Texas Law Review 74(2):259-344.
Baumann, Z. 1993. Postmodern Ethics. London: Routledge.

Beck, U. 1997. Subpolitics: Ecology and the Disintegration of Institutional Power. Organization and Environment 10(1):52-65.

Bond, P. 2011. Emissions trading, new enclosures and eco-social contestation. Antipode 44(3):684-701.

Brand, U. and C. Gorg. 2008. Conflicts in Environmental Regulation and the Internationalization of the State: Contested Terrains. London: Routledge.

Brechin, S. 2009. Corporate Contributions to Transnational Conservation NGOs: Private International Transfers or Transactions? International Studies Review 11:423-30.

Brockington, D. and R. Duffy 2011. Capitalism and Conservation. London: Wiley.

Büscher, B. in press. "Nature 2.0” Geoforum

Büscher, B., S. Sullivan, K. Neves, J. Igoe and D. Brockington. 2012. Towards a Synthesized Critique of Neoliberal Biodiversity, Conservation. Capitalism Nature Socialism 23(2):4-30.

Castree, N. 2008. Neoliberalising nature: the logics of deregulation and reregulation. Environment and Planning A 40:131-152.

Corson, C. 2010. Shifting Environmental Governance in a Neoliberal World: US AID for

Conservation, Antipode 42(3): 576-602.

Corson, C. and K. I. MacDonald. 2012. Enclosing the global commons: the convention on biological diversity and green grabbing. Journal of Peasant Studies 39(2):263-283.

Ebert, T. L. 1999. Globalization, Internationalism, and the Class Politics of Cynical Reason. Nature, Society and Thought 12(4):389-410. 
Eyerman, R. and A. Jamison. 1989. Environmental knowledge as an organizational weapon: The case of Greenpeace. Social Science Information 28(1):99-118.

Fassin, D. 2012. Humanitarian Reason: A Moral History of the Present. Berkeley: University of California Press.

Goldman, M. 2005. Imperial Nature: The World Bank and Struggles for Social Justice in the Age of Globalization. New Haven: Yale University Press.

Guha, R., and J. Martinez-Alier. 1997. Varieties of Environmentalism. Oxford: Earthscan.

Haraway, D. J. 1989. Primate Visions: Gender, Race, and Nature in the World of Modern Science. New York: Routledge.

Harter, J. 2004. Environmental justice for whom? Class, new social movements and the environment Labour/Le Travail 54(3):83-119.

Harvey D 2000. Spaces of Hope. Berkeley: University of California Press.

Huyssen, A. 1988. Foreword: The Return of Diogenes as Postmodern Intellectual. In Critique of Cynical Reason, Sloterdijk, P. Minneapolis: University of Minnesota Press.

Huyssen, A. 1994. Twilight Memories: Marking Time in a Culture of Amnesia. London: Routledge.

Igoe, J. 2010. The Spectacle of Nature in the Global Economy of Appearances: Anthropological Engagements with the Spectacular Mediations of Transnational Conservation. Critique of Anthropology 30(4):375-97.

Kelly, A. 2011. Conservation practice as primitive accumulation. Journal of Peasant Studies 38(4):683701.
Lampel, J. and Meyer, A.D. 2008. Fieldconfiguring events as structuring mechanisms: how conferences, ceremonies, and trade shows constitute new technologies, industries, and markets, Journal of Management Studies 45(6): 1025-1035

Latour, B. 1999. Pandora's Hope: Essays on the Reality of Science Studies. Cambridge: Harvard University Press.

Latour, B. 2005. Reassembling the Social: An Introduction to Actor-Network-Theory. Oxford: Oxford University Press.

Lewis, D. 2003. NGOs, Organizational Culture, and Institutional Sustainability. The Annals of the American Academy of Political and Social Science 590:212-226.

MacDonald, K. I. 2010a. The Devil is in the (bio)Diversity: Private Sector 'Engagement' and the Restructuring of Biodiversity Conservation. Antipode 42(3):513-550.

MacDonald, K. I. 2010b. Business, Biodiversity and New 'Fields' of Conservation: The World Conservation Congress and the Renegotiation of Organizational Order. Conservation and Society 8(4):256-275.

MacDonald, K. I. (in press) Scales of Environmental Governance and the Configuration of

Transnational Institutional Space. In B. Müller (ed) The Anthropology of International Organizations: The Inner Workings of a Global Ideal. London: Pluto Press.

MacDonald, K. I. and C. Corson. 2012. 'TEEB Begins Now': A Virtual Moment in the Production of Natural Capital Development and Change 43(1):159184.

Martinez-Alier, J. 2003. The Environmentalism of the Poor: A Study of Ecological Conflicts and Valuation. Cheltenham: Edward Elgar. 
Meghani, Z. and J. Kuzma. 2011. The "Revolving Door" between Regulatory Agencies and Industry: A Problem That Requires Reconceptualizing Objectivity. Journal of Agricultural and Environmental Ethics 24(6):575-599.

O'Doherty, D. and H. Willmott. 2001. Debating Labour Process Theory: The issue of subjectivity and the relevance of poststructuralism. Sociology 35(2):457476.

Radin, M. J. 1996. Contested Commodities: The Trouble with Trade in Sex, Children, Body Parts and Other Things. Cambridge, MA: Harvard University Press.

Rigling Gallagher, D. 2007. The Professionalization of Sustainability. In Organizations and the Sustainability Mosaic, edited by B. Husted and S. Sharma. Northampton, MA: Edward Elgar.

Robertson, M. 2007. Discovering Price in all The Wrong Places: The Work of Commodity Definition and Price Under Neoliberal Environmental Policy. Antipode 39(3):500-526.

Rootes C ed 2003 The Transformation of Environmental Activism: An Introduction Oxford University Press, Oxford.

Rootes, C. 2004. Environmentalism in The Blackwell Companion to Social Movements, edited by D. A. Snow, S. A. Soule, and H. Kriesi. Oxford: Blackwell.

Rosen, M. 2000. Turning Words, Spinning Worlds: Chapters in Organizational Ethnography. Amsterdam: Harwood Academic Publishers.

Rostow, W. W. 1960. The Stages of Economic Growth: A Non-Communist Manifesto. Cambridge: Cambridge University Press.

Schama, S. 1996. Landscape and Memory. New York: Vintage.
Schlossberg, D. and J. S. Dryzek. 2002. Political Strategies of American Environmentalism: Inclusion and Beyond. Society and Natural Resources 15(9):787804.

Scott, W. R., Rueff, M.,Mendel, P. and Caronna, C. A. (2000). Institutional Change and Healthcare Organizations. Chicago: University of Chicago Press.

Sloterdijk, P. 1988. Critique of Cynical Reason. Minneapolis: University of Minnesota Press.

Sullivan, S. 2012. Banking nature? The spectacular financialisation of environmental conservation. Antipode. DOI: 10.1111/j.1467-8330.2012.00989.x

Tarrow, S. 1994. Power in Movement: Collective Action, Social Movements and Politics. Cambridge: Cambridge University Press.

ten Brink, P. et al. 2009. TEEB - The Economics of Ecosystems and Biodiversity for National and International Policy Makers - Summary: Responding to the Value of Nature. Geneva: UNEP.

Tilly, C. 2006. Regimes and Repertoires. Chicago: University of Chicago Press.

Torgerson, D. 1997. Professionalism and the voices of dissent: The case of environmentalism. Polity 29(3):345-374.

Trumpy, A. J. 2008. Negotiation: The Mechanisms Behind Co-Optation and Corporate Reform. Social Problems 55(4):480-510.

Worster, D. 1993. The Shaky Ground of Sustainability in Global Ecology: A NEW Arena of Political Conflict, edited by W. Sachs. London: Zed Books.

Žižek, S. 1989. The Sublime Object of Ideology. New York: Verso. 